\title{
Stability of an Amorphous Alloy of the Mm-Al-Ni-Cu System
}

\section{Carlos Triveño Rios ${ }^{\mathrm{a} *}$, Luis César Rodrígues Aliaga ${ }^{\mathrm{b}}$, Claudio Shyinti Kiminami ${ }^{\mathrm{b}}$,}

\author{
Claudemiro Bolfarini ${ }^{\mathrm{b}}$, Walter José Botta Filho ${ }^{\mathrm{b}}$
}

\author{
${ }^{a}$ Centro de Engenharia, Modelagem e Ciências Sociais Aplicadas, Universidade Federal do ABC - UFABC, \\ Rua Sta. Adélia, 166, CEP 09210-170, Santo André, SP, Brasil \\ ${ }^{\mathrm{b}}$ Departamento de Engenharia de Materiais, Universidade Federal de São Carlos - UFSCar, \\ Rod. Washington Luiz, Km 235, CEP 13565-905, São Carlos, SP, Brazil
}

Received: October 12, 2011; Revised: March 05, 2012

\begin{abstract}
An investigation was made of the stability of melt-spun ribbons of $\mathrm{Mm}_{55} \mathrm{Al}_{25} \mathrm{Ni}_{10} \mathrm{Cu}_{10}$ $(\mathrm{Mm}=$ Mischmetal $)$ amorphous alloy. The structural transformations that occurred during heating were studied using a combination of X-ray diffraction (XRD) and differential scanning calorimetry (DSC). Crystallization took place through a multi-stage process. The first stage of transformation corresponded to the formation of a metastable phase followed by cfc-Al precipitation, while in the second stage, exothermic transformations led to the formation of complex and unidentified $\mathrm{Mm}(\mathrm{Cu}$, $\mathrm{Ni})$ and $\mathrm{MmAl}(\mathrm{Cu}, \mathrm{Ni})$ phases. The transformation curves recorded from isothermal treatments at $226{ }^{\circ} \mathrm{C}$ and $232{ }^{\circ} \mathrm{C}$ indicated that crystallization occurred through nucleation and growth, with diffusion-controlled growth occurring in the first crystallization stage. The supercooled liquid region, $\Delta T_{x}$, at $40 \mathrm{~K} / \mathrm{min}$ was $\sim 80 \mathrm{~K}$. This value was obtained by the substitution of $\mathrm{Mm}(=\mathrm{Ce}+\mathrm{La}+\mathrm{Nd}+\mathrm{Pr})$ for $\mathrm{La}$ or $\mathrm{Ce}$, saving chemical element-related costs.
\end{abstract}

Keywords: mischmetal based glass alloys, crystallization, thermal stability

\section{Introduction}

Rare earth (RE) metals are the main alloying elements for glass formation in ternary and quaternary RE-Al-TM amorphous alloys. Many studies of RE-based alloys with high glass forming ability (GFA), such as La-Al-Ni ${ }^{1}$, $\mathrm{La}-\mathrm{Al}-\mathrm{Cu}^{2,3}, \mathrm{La}-\mathrm{Al}-\mathrm{Ni}-\mathrm{Cu}^{2,3}, \mathrm{La}-\mathrm{Al}-\mathrm{Cu}-\mathrm{Ni}-\mathrm{Co}^{4}, \mathrm{Nd}-\mathrm{Fe}-\mathrm{Al}^{5}$ and $\mathrm{Ce}-\mathrm{Al}-\mathrm{Ni}-\mathrm{Cu}^{6}$, have shown that they are promising structural materials. La-based ${ }^{4}, \mathrm{Ce}-\mathrm{Al}-\mathrm{M}(\mathrm{M}=\mathrm{Cu}, \mathrm{Co}, \mathrm{Ni})$ and $\mathrm{Mm}-\mathrm{Al}-\mathrm{Cu} \mathrm{BMG}{ }^{7,8}$, in particular, have been prepared in the form of bulk glass rods with diameters of 1 to $10 \mathrm{~mm}$, using the high-pressure die casting method.

Bulk metallic glasses (BMGs) have attracted much attention due to their considerable scientific and technical importance ${ }^{9-11}$. These alloys have a large supercooled liquid region of up to $80 \mathrm{~K}$ before crystallization and a very low glass transition temperature $(>0.6)^{12}$. However, they may present disadvantages such as catastrophic fracture due to localized shear band propagation during mechanical tests and relatively low ductility, which limit their engineering applications $^{13,14}$.

In situ fabrication of RE-based BMGs such as the La-Al-Ni-Cu system has been reported recently ${ }^{15,16}$, showing plasticity allied to moderate strength at room temperature. Mm-based BMGs have also been examined as an alternative to RE-based BMGs, due to the latter's high $\operatorname{cost}^{17}$. However, the GFA of Mm-based BMGs require further improvement, since it is still significantly lower than that of La-based BMGs ${ }^{17}$.

It should be noted that mischmetal is an unpurified alloy whose composition normally contains $\mathrm{Ce}, \mathrm{La}, \mathrm{Nd}$ and Pr rare

*e-mail: carlos.triveno@ufabc.edu.br earth elements. Mischmetal therefore has an obvious cost advantage compared to single purified rare earth metals. Therefore, the development of Mm-based BMGs with high GFA is particularly important for technological applications. Some researchers have reported the successful fabrication of Mm-based BMG matrix composite by substituting $\mathrm{Mm}$ for $\mathrm{La}$ and $\mathrm{Ce}$ in $\mathrm{La}-\mathrm{Al}-\mathrm{Ni}-\mathrm{Cu}$ and $\mathrm{Ce}-\mathrm{Al}-\mathrm{Ni}-\mathrm{Cu}$ systems ${ }^{8}$.

Many technological applications of BMGs require that such materials should be thermally stable with time and temperature during use. The thermal stability of BMGs materials is an important factor related to crystallization, activated process of transition from disordered amorphous structure to ordered crystal structure. In order to determine the thermal stability of BMGs, the crystallization kinetics it is examined by means of differential thermal analysis techniques. On the other hand, Kissinger's well-known method is usually employed to determine the crystallization activation energy, $E c^{4,8}$. According to this method, $E c$ can be expressed as:

$$
\operatorname{Ln}\left(\frac{\beta}{T_{p}^{2}}\right)=-\frac{m}{n}\left(\frac{E_{c}}{R T_{p}}\right)+A
$$

where $\beta$ is the heating rate in Kelvin per second $(\mathrm{K} / \mathrm{s})$, $T_{p}$ corresponds to the peak temperature in DSC curves in nonisothermal conditions, $R$ is the gas constant, and $A$ is a constant. The main aim of the present investigation was to study the thermal stability and crystallization of amorphous $\mathrm{Mm}_{55} \mathrm{Al}_{25} \mathrm{Ni}_{10} \mathrm{Cu}_{10}$ melt-spun ribbons. 


\section{Experimental Procedure}

Ingots of $\mathrm{Mm}_{55} \mathrm{Al}_{25} \mathrm{Ni}_{10} \mathrm{Cu}_{10}$ alloy were prepared by arc-melting from high-purity $\mathrm{Al}, \mathrm{Ni}, \mathrm{Cu}$ and $\mathrm{Mm}$ in a highly pure argon atmosphere and were then Ti-gettered. The nominal composition of $\mathrm{Mm}$ is 45.1 at. $\% \mathrm{Ce}$, 33.6 at. $\% \mathrm{La}, 5.4$ at. $\% \mathrm{Pr}$ and 15.9 at. $\% \mathrm{Nd}$, plus a few impurities. The ingots were remelted several times to ensure their homogeneity. Amorphous ribbons were prepared using a single-roller melt-spinning technique under an argon atmosphere with a $\mathrm{Cu}$ wheel rotating at a speed of $\sim 40 \mathrm{~m}^{-1}$. The resulting ribbons were $2.5 \mathrm{~mm}$ wide, $30-40 \mu \mathrm{m}$ thick and several meters long. The as-quenched ribbons presented $180^{\circ}$ bending ductility. The amorphous structure of the ribbon samples was examined by XRD, using $\mathrm{CuK} \alpha$ radiation $(\lambda=0.1542 \mathrm{~nm})$ in a Rigaku diffractometer with $\theta-2 \theta$ geometry. Thermal analyses were performed in a differential scanning calorimeter (DSC 200 F3 Maia), in a pure argon atmosphere. Continuous heating studies were performed at a heating rate of $5-40 \mathrm{~K} / \mathrm{min}$. Isothermal treatments were carried out by heating the samples continuously at a rate of $60 \mathrm{~K} / \mathrm{min}$ up to the treatment temperature.

\section{Results and Discussion}

The normalized DSC curves of as-quenched amorphous ribbon treated at different heating rates $(5-40 \mathrm{~K} / \mathrm{min})$ are depicted in Figure 1. Increasing the heating rate $(\beta)$ caused all the exothermic peaks to shift to higher temperatures and broadened all the peaks. Table 1 summarizes the transformation temperatures obtained from the thermograms. The alloy shows glassy characteristics with a clear glass transition temperature, $T_{g}$, preceding the onset crystallization temperature, $\mathrm{T}_{\text {onset}}$, thus exhibiting a supercooled liquid region $\Delta T_{X}\left(\Delta T_{X}=T_{X I}-T_{g}\right)$. The transition from the glassy to the supercooled liquid state, which is characterized by the endothermic reaction, takes place before crystallization, and its onset temperature increases from $183{ }^{\circ} \mathrm{C}$ to $275{ }^{\circ} \mathrm{C}$ with increasing heating rate. The supercooled liquid region of this alloy varies in the range of $65-80{ }^{\circ} \mathrm{C}$, also as a function of increasing heating rate. The inset in Figure 1 shows typical melting curves for two heating rates ( 20 and $40 \mathrm{~K} / \mathrm{min}$ ). The curves reveal a sharp initial melting event at the onset of the melting temperature, $T_{m}$, followed by two very broad melting peaks. Increasing the heating rate caused the liquidus temperature, $T_{l}$, to increase from $544(20 \mathrm{~K} / \mathrm{min})$ to $555^{\circ} \mathrm{C}(40 \mathrm{~K} / \mathrm{min})$, while the $T_{m}$ remained stable at around $410^{\circ} \mathrm{C}$. However, there is a significant difference of $145^{\circ} \mathrm{C}$ between $T_{m}$ and $T_{l}$, indicating that the alloy's composition is not eutectic.

The activation energy for crystallization of an amorphous structure subjected to a continuous heating condition was

Table 1. Transformation parameters obtained from the continuous heating experiments at different cooling rates.

\begin{tabular}{|c|c|c|c|c|c|}
\hline $\begin{array}{c}\beta \\
K / \min \end{array}$ & $\begin{array}{c}\text { Enthalpy } \\
\Delta \mathbf{H}_{\mathrm{P} 1}\left(\mathrm{~J}^{\left.-g^{-1}\right)}\right.\end{array}$ & $\begin{array}{c}\mathbf{T}_{\mathbf{g}} \\
\left({ }^{\circ} \mathbf{C}\right)\end{array}$ & $\begin{array}{c}\mathbf{T}_{\mathrm{Pl}} / \mathbf{T}_{\text {onset }} \\
\left({ }^{\circ} \mathbf{C}\right)\end{array}$ & $\begin{array}{l}\Delta \mathbf{T}_{\mathbf{X}} \\
\left({ }^{\circ} \mathbf{C}\right)\end{array}$ & $\begin{array}{c}\mathbf{T}_{\mathbf{P} 2} / \mathbf{T}_{\text {onset }} \\
\left({ }^{\circ} \mathbf{C}\right)\end{array}$ \\
\hline 5.0 & -33.8 & 183.2 & $249.6 / 247.7$ & 64.6 & $330.2 / 311$ \\
\hline 10.0 & -3 & 185.9 & $257.9 / 256.1$ & 71.5 & $339.3 / 310$ \\
\hline 20.0 & -39.9 & 189 & $266.4 / 26$ & 76.0 & $353.0 / 316$ \\
\hline 40.0 & -45.5 & 195.5 & $275.6 / 274.6$ & 79.5 & $362.4 / 332$ \\
\hline
\end{tabular}

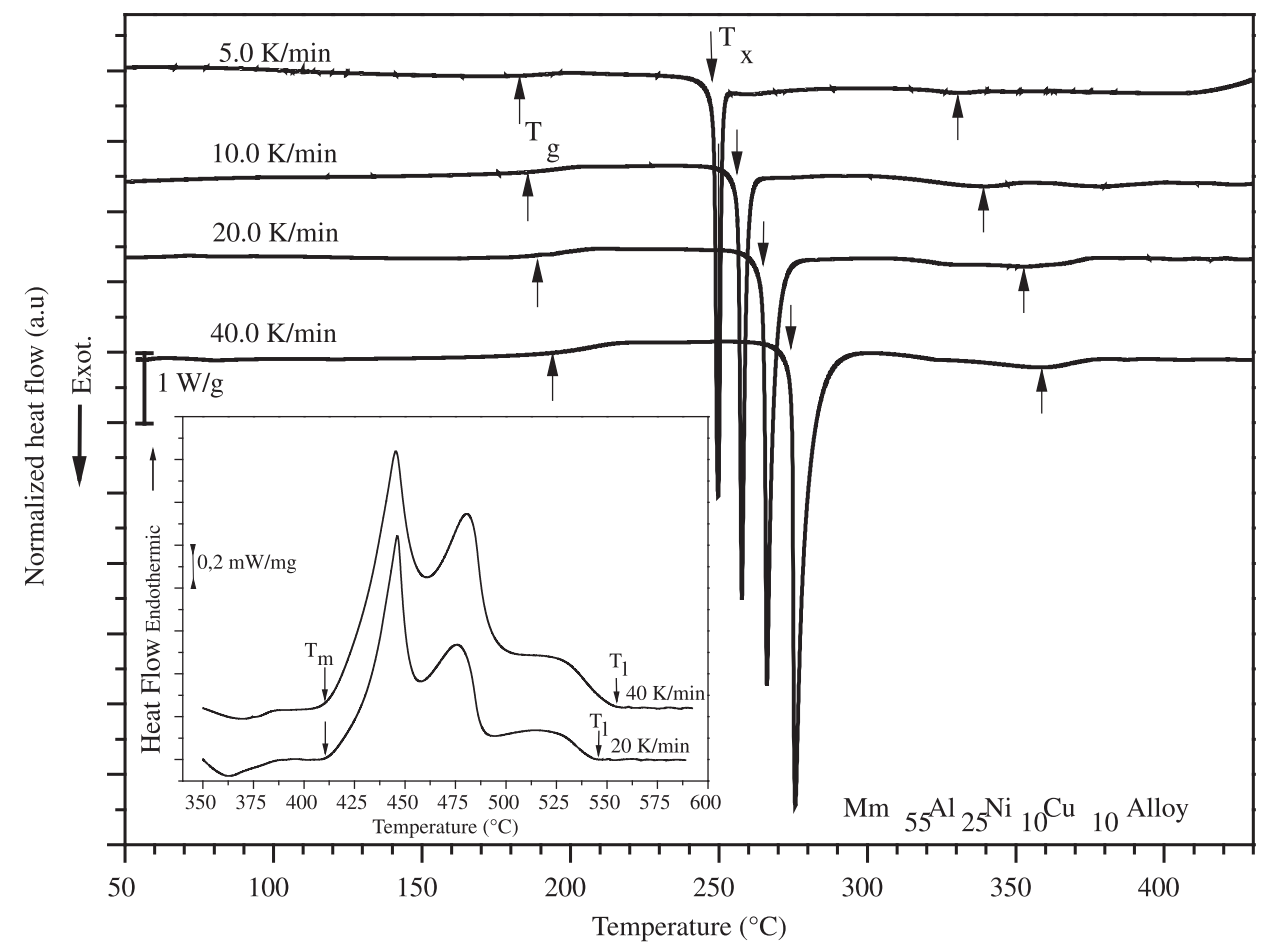

Figure 1. Continuous heating DSC-curves obtained at different heating rates showing the glass transition for $\mathrm{Mm}_{55} \mathrm{Al}_{25} \mathrm{Ni}_{10} \mathrm{Cu}_{10}$ alloy. The inset shows melting curves for heating rates of 20 and $40 \mathrm{~K} / \mathrm{min}$. 
deduced from the Kissinger model (Equation 1$)^{18}$. Figure 2 shows that the Kissinger plot $\operatorname{R} \ln \left(\beta / T_{p, g}\right)$ vs. $\left(1 / T_{p, g}\right)$ yields an approximately straight line. The activation energy can be determined from the slope of the line for both the crystallization stages and the glass transition. Here, $T_{p, g}$ is the glass transition temperature or peak crystallization temperature. The activation energies for both glass transition and crystallization events are evaluated from the slope of the Kissinger straight line and the heat released during continuous heating. Note that the activation energy for devitrification $\left(E a_{g}\right)$ is high, i.e., $331 \mathrm{~kJ} \cdot \mathrm{mol}^{-1}$, suggesting a

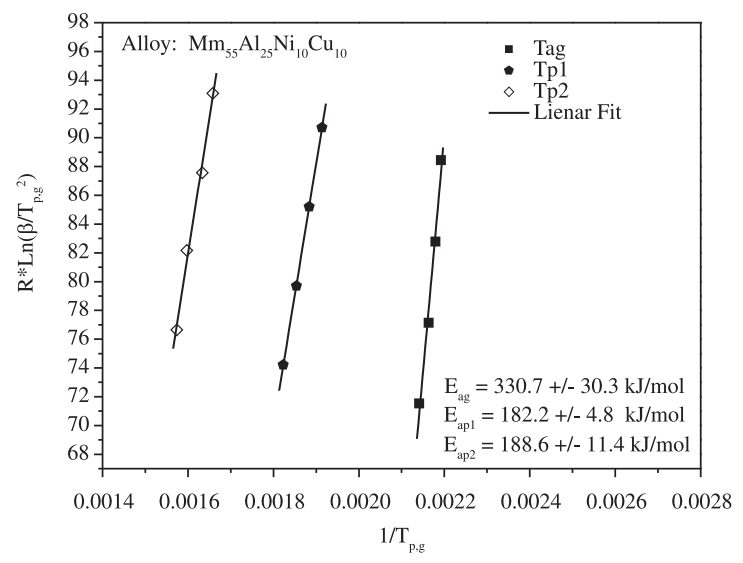

Figure 2. Kissinger plots showing activation energy for the glass transition (Tg) and for the two exothermic peaks $\left(\mathrm{T}_{\mathrm{p} 1}\right.$ and $\left.\mathrm{T}_{\mathrm{p} 2}\right)$. higher thermal stability of the amorphous structure, which would lead to more sluggish nucleation and subsequent crystal growth upon heating ${ }^{19}$. On the other hand, the activation energies of the first and second exothermic peaks are 182 and $189 \mathrm{~kJ} \mathrm{~mol}^{-1}$ and correspond, as suggested by the XRD pattern, to polyphasic crystallization, which involves metastable and intermetallic phases.

Figure 3 presents the XRD patterns of the as-quenched and partially crystallized ribbons, as well as the as-cast $\left(\mathrm{Mm}_{55} \mathrm{Al}_{25} \mathrm{Ni}_{10} \mathrm{Cu}_{10}\right)$ sample. To achieve partial crystallization, the ribbon was heated continually at $60 \mathrm{~K} / \mathrm{min}$ up to $220{ }^{\circ} \mathrm{C}$ for different annealing times, as indicated in the inset of Figure 3. For comparison, the XRD pattern of the melt-spun ribbon was plotted, and the Bragg peaks of $\mathrm{Ce}_{3} \mathrm{Al}$ and AlCeNi taken from JCPDS cards are clearly visible. The characteristic diffuse halo of an amorphous structure is visible in the XRD pattern of the melt-spun ribbon. This characteristic was maintained in the sample annealed for 16 minutes at $220{ }^{\circ} \mathrm{C}$, before the beginning of the nucleation/growth process. However, with longer annealing times, e.g., 28 minutes (first peak), precipitation of metastable phases occurred and possible first traces of $\mathrm{Mm}_{3} \mathrm{Al}$ appeared, which remained up to 32 minutes (close to the second peak). In the annealing interval of 32 and 40 minutes, complete crystallization of the amorphous phase was observed, with the formation of $\mathrm{Al}_{3} \mathrm{Ce}, \mathrm{AlCeNi}$ and unknown phases, all of which precipitated simultaneously, resulting in the disappearance of some of the peaks of metastable phases. On the other

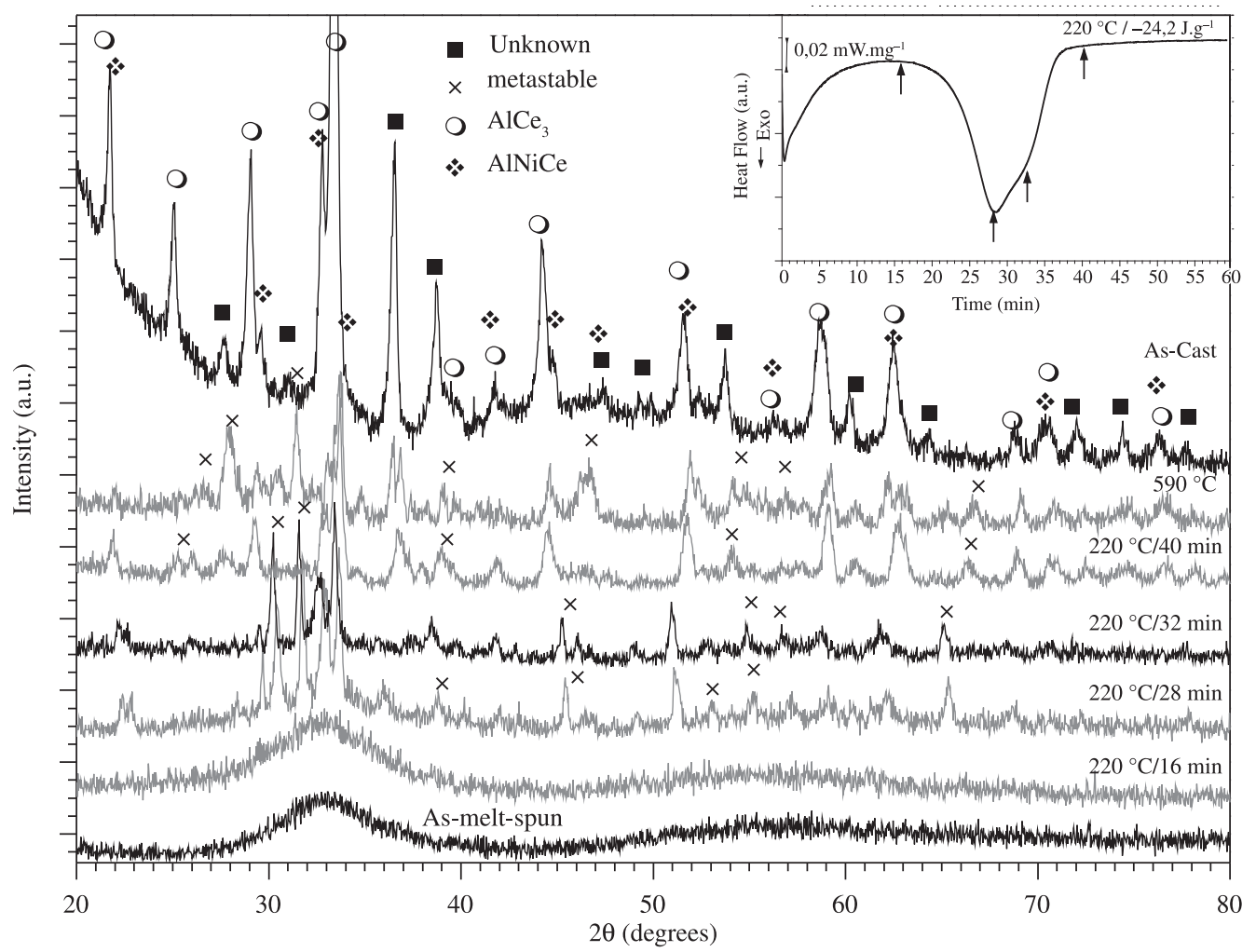

Figure 3. X-ray diffraction patterns corresponding to the melt-spun ribbon heated continually at $60 \mathrm{~K} / \mathrm{min}$ up to $220{ }^{\circ} \mathrm{C}$ for different annealing times (partially crystallized) and the as-cast $\left(\mathrm{Mm}_{55} \mathrm{Al}_{25} \mathrm{Ni}_{10} \mathrm{Cu}_{10}\right)$ samples. 
hand, the Bragg peaks of crystalline phases clearly visible in the XRD pattern of the cross-section of the as-cast sample are in good agreement with the phases precipitated from the amorphous structure. However, the position of the peaks shifted slightly, possibly due to the mixture of RE elements in $\mathrm{Mm}$, which can induce the expansion or contraction of crystalline structures. The position of the Bragg peaks was very similar to those of $\mathrm{AlCeNi}$ and $\mathrm{Ce}_{3} \mathrm{Al}$ that have been reported previously in XRD patterns obtained from arc-melted $\mathrm{Mm}_{55} \mathrm{Al}_{25} \mathrm{Ni}_{10} \mathrm{Cu}_{10}$ master alloy ${ }^{17}$. This is due to the fact that $\mathrm{Mm}$, which is constituted of the elements $\mathrm{Ce}$, $\mathrm{La}, \mathrm{Nd}$ and $\mathrm{Pr}$, exhibits crystallization properties very similar to those of Mm alloy; hence, no remarkable differences are detectable between the XRD patterns of samples annealed at equivalent stages of crystallization ${ }^{20}$.

Figure 4 shows a typical backscatter SEM micrograph of the as-cast $\left(\mathrm{Mm}_{55} \mathrm{Al}_{25} \mathrm{Ni}_{10} \mathrm{Cu}_{10}\right)$ sample. The microstructure shows hexagonal phases with contrasting white and dark gray regions. An EDS/SEM analysis indicated that the composition of the dark gray phase is $\sim \mathrm{Mm}_{33,9} \mathrm{Al}_{30,2}(\mathrm{Ni}, \mathrm{Cu})^{8,30}$ and that of the white phase is $\sim \mathrm{Mm}_{67,1} \mathrm{Al}_{25,5}(\mathrm{Ni}, \mathrm{Cu})^{4,7}$. This analysis suggests that the characteristics of these phases are similar to those of AlRENi (AlCeNi) and $\mathrm{RE}_{3} \mathrm{Al}\left(\mathrm{Ce}_{3} \mathrm{Al}\right)$ phases identified in the JCPDS database. Moreover, other phases appear with intermediate contrasts and compositions varying from $\mathrm{Mm}_{36,1} \mathrm{Al}_{21,4} \mathrm{Ni}_{12,4} \mathrm{Cu}_{30,1}$ to $\mathrm{Mm}_{42,1} \mathrm{Al}_{20,4} \mathrm{Ni}_{9,4} \mathrm{Cu}_{28,1}$ (in at.\%). However, these phases were not identified in the JCPDS database and probably correspond to the unknown phase visible in the XRD patterns.

The inset in Figure 3 shows an exothermic peak attributed to the nucleation/growth process, indicating that an incubation period occurred before the beginning of the phase transformation became detectable. This transformation involves the overlapping of two crystallization stages and likely corresponds to the exothermic peaks visible in the DSC curves (Figure 1), indicating that the nucleation/growth process is fast and complex due to the initial precipitation of metastable phases followed by the precipitation of unknown AlMmNi, $\mathrm{Mm}_{3} \mathrm{Al}$ phases. Conversely, the asymmetric isothermal thermograms shown in the inset of Figure 3 correspond to diffusion-controlled growth in alloys that do not present eutectic crystallization ${ }^{21}$. This

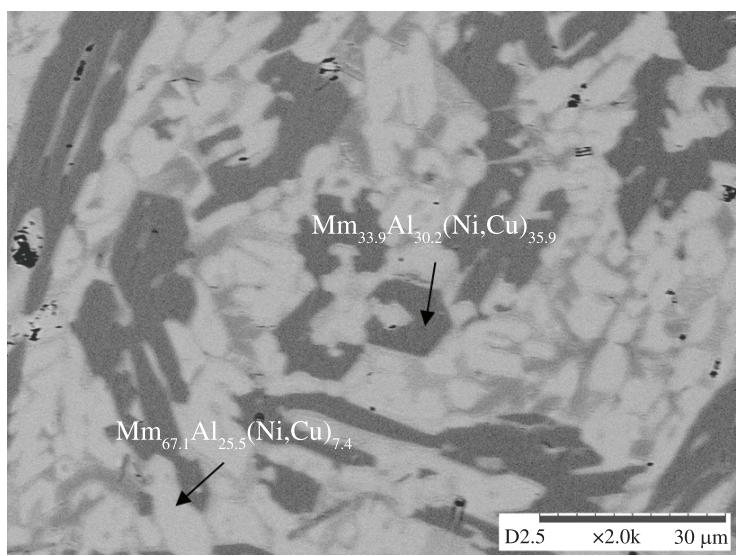

Figure 4. Typical microstructure of the as-cast $\left(\mathrm{Mm}_{55} \mathrm{Al}_{25} \mathrm{Ni}_{10} \mathrm{Cu}_{10}\right)$ sample. is in good agreement with the SEM and DRX results. The isothermal analysis indicated that the energy released was lower $\left(-24{\left.\mathrm{~J} . \mathrm{g}^{-1}\right)}\right.$ than that released during continuous heating, confirming the activation of the nucleation/growth mechanism characteristic of intermetallic compounds. In this case, the larger amount of released heat may have been due to the activation energy for nucleation of the metastable intermetallic compounds, to which the contribution of activation energy for nucleation is much smaller than the activation energy for growth ${ }^{22}$.

In short, the crystallization process of $\mathrm{Mm}_{55} \mathrm{Al}_{25} \mathrm{Ni}_{10} \mathrm{Cu}_{10}$ amorphous alloy under both continuous and isothermal heating conditions can be expressed as follows: amorphous $\rightarrow$ metastable phase $+\mathrm{Mm}_{3} \mathrm{Al}$ $\rightarrow \mathrm{Mm}_{3} \mathrm{Al}+\mathrm{MmAl}(\mathrm{NiCu})+$ unknown phase. This suggests that the $(\mathrm{CeLaNdPr})_{3} \mathrm{Al}$ phase initiates the crystallization process in the alloy after precipitation of the metastable phase, probably due to the dissimilar diffusion coefficients of the components and also because of the strong interaction between dissimilar Mm-Al, Mm-Ni and $\mathrm{Mm}-\mathrm{Cu}$ atoms ${ }^{23}$. However, the main peak corresponds to the $\mathrm{Mm}-\mathrm{Mm}$ correlation, giving rise to the metastable phase, which is a supersaturated one that later gives rise to $\mathrm{Mm}_{3} \mathrm{Al}$ and $\mathrm{AlMm}(\mathrm{Ni}, \mathrm{Cu})$ primary phases. On the other hand, the activation energies for the crystallization of different phases in $\mathrm{Mm}_{55} \mathrm{Al}_{25} \mathrm{Ni}_{10} \mathrm{Cu}_{10}$ amorphous alloy have been determined as occurring at 182 and $187 \mathrm{~kJ} \mathrm{~mol}^{-1}$, which are very close to the activation energies for self-diffusion of $\mathrm{Ce}$, La and $\mathrm{Pr}$ in $\mathrm{Mm}$-based amorphous alloy ${ }^{24}$. It should be noted that $\mathrm{Ce}_{3} \mathrm{Al}$, $\mathrm{La}_{3} \mathrm{Al}, \mathrm{Nd}_{3} \mathrm{Al}$ and $\mathrm{Pr}_{3} \mathrm{Al}$ phases are difficult to distinguish clearly from one other because they have the same crystalline structure with similar lattice constants and nearly the same atomic radius ${ }^{25}$; hence, these phases are considered to be $\mathrm{Mm}_{3} \mathrm{Al}$. Conversely, the high activation energy (331 kJ. $\mathrm{mol}^{-1}$ ) for crystallization of amorphous $\mathrm{Mm}_{55} \mathrm{Al}_{25} \mathrm{Ni}_{10} \mathrm{Cu}_{10}$ alloy implies good thermal stability. This value is similar to that reported in other studies, e.g., $323 \mathrm{~kJ} \mathrm{~mol}^{-1}$ for amorphous $\mathrm{Mm}_{55} \mathrm{Al}_{25} \mathrm{Ni}_{10} \mathrm{Cu}_{10}$ alloy ${ }^{26}$ and $\mathrm{La}_{55} \mathrm{Al}_{25} \mathrm{Ni}_{20}$ metallic glass ${ }^{27}$. An interesting point to keep in mind is that low activation energies are generally associated with local atomic rearrangements and high activation energies with the cooperative movement of atomic groups, which result in viscous flow ${ }^{26}$

Table 2 describes the thermal properties of amorphous alloys with compositions close to the $\mathrm{Mm}_{55} \mathrm{Al}_{25} \mathrm{Ni}_{10} \mathrm{Cu}_{10}$ alloy studied here, which has been investigated by other researchers at heating rates of 20 and $40 \mathrm{~K} / \mathrm{s}$. The following thermal parameters were evaluated: $T_{g}, T_{X}, \Delta T_{X}\left(=T_{X}-T_{g}\right)$, $T_{l}, T_{m}, T_{r g}\left(=T_{g} / T_{l}\right), T_{g} / T_{X}, \gamma\left(=T_{X} /\left(T_{g}+T_{l}\right)\right)$, and $K\left(=\left(T_{X}-T_{g}^{g}\right) /\right.$ $\left.\left(T_{-}-T_{X}\right)\right)$. Although these parameters show reasonable correlations with the GFA of numerous metallic glass alloys, they still do not reflect the real GFA of alloys in many cases ${ }^{3,28}$. Many GFA indicators related to characteristic temperatures (i.e., $T_{g}, T_{x}$ and $T_{l}$ ) are derived based on both crystallization resistance and liquid stability. In other words, the GFA of glass-forming liquids cannot be attributed solely to the stability of the liquid phase ${ }^{29}$. However, for purposes of discussion, parameters such as $T / T g$ and $T_{r g}$ are quantitative measurements that serve to indicate crystallization resistance and liquid stability, respectively. 
Table 2. Thermal parameters for the crystallization of RE-Al-(Cu,Ni) alloys during continuous heating.

\begin{tabular}{|c|c|c|c|c|c|c|c|c|c|c|}
\hline Alloy & $\begin{array}{l}\mathbf{T}_{\mathrm{g}} \\
(\mathbf{K})\end{array}$ & $\begin{array}{l}\mathbf{T}_{\mathbf{x} 1} \\
(\mathbf{K})\end{array}$ & $\begin{array}{c}\Delta \mathbf{T}_{\mathbf{x}}= \\
T_{X}-T_{\mathrm{g}} \\
(\mathbf{K})\end{array}$ & $\begin{array}{c}\mathbf{T}_{\mathrm{L}} \\
(\mathbf{K})\end{array}$ & $\begin{array}{l}\mathbf{T}_{\mathrm{m}} \\
(\mathbf{K})\end{array}$ & $T_{\mathrm{rg}}=T_{\mathrm{g}} / T_{\mathrm{L}}$ & $T_{\mathrm{g}} / T_{\mathbf{x} 1}$ & $\begin{array}{c}\gamma \\
\mathbf{T}_{\mathbf{x}} / \\
\left(\mathbf{T}_{\mathrm{g}}+\mathbf{T}_{\mathrm{L}}\right)\end{array}$ & $\begin{array}{c}\mathbf{K}= \\
\left(\mathbf{T}_{\mathbf{x}}-\mathbf{T}_{\mathrm{g}}\right) / \\
\left(\mathbf{T}_{\mathrm{L}}-\mathbf{T}_{\mathbf{x}}\right)\end{array}$ & Remarks \\
\hline $\mathrm{La}_{55} \mathrm{Al}_{25} \mathrm{Ni}_{20}$ & 491.0 & 555.0 & 64.0 & 941.0 & $711.6^{[32]}$ & 0.590 & 0.885 & 0.388 & 0.166 & [25] \\
\hline $\mathrm{La}_{55} \mathrm{Al}_{25} \mathrm{Ni}_{15} \mathrm{Cu}_{5}$ & 473.6 & - & - & 899.6 & $659.7^{[32]}$ & - & - & - & - & {$[32]$} \\
\hline $\mathrm{La}_{55} \mathrm{Al}_{25} \mathrm{Ni}_{10} \mathrm{Cu}_{10}$ & 467.4 & 547.2 & 79.8 & 835.0 & $662.1^{[32]}$ & 0.560 & 0.854 & 0.420 & 0.278 & {$[2,32]$} \\
\hline $\mathrm{La}_{55} \mathrm{Al}_{25} \mathrm{Ni}_{10} \mathrm{Cu}_{10}$ & 474.0 & 557.0 & 84.0 & 831.6 & - & 0.570 & 0.851 & 0.427 & 0.302 & {$[4,33]$} \\
\hline $\mathrm{La}_{55} \mathrm{Al}_{25} \mathrm{Ni}_{5} \mathrm{Cu}_{10} \mathrm{Co}_{5}$ & 465.2 & 541.8 & 76.6 & 822.5 & $660.9^{[32]}$ & 0.566 & 0.859 & 0.421 & 0.273 & {$[2,32]$} \\
\hline $\mathrm{La}_{55} \mathrm{Al}_{25} \mathrm{Cu}_{20}$ & 455.9 & 494.8 & 38.9 & 896.1 & $672.1^{[32]}$ & 0.509 & 0.921 & 0.366 & 0.097 & {$[2,32]$} \\
\hline $\mathrm{Mm}_{55} \mathrm{Al}_{25} \mathrm{Ni}_{10} \mathrm{Cu}_{10}$ & 472.0 & 540.0 & 68.0 & - & - & 0.510 & 0.874 & 0.3864 & - & {$[17]$} \\
\hline $\mathrm{Mm}_{55} \mathrm{Al}_{25} \mathrm{Ni}_{10} \mathrm{Cu}_{10}$ & 483.0 & 553.7 & 70.7 & - & - & - & 0.872 & - & - & [7] \\
\hline $\mathrm{Mm}_{55} \mathrm{Al}_{25} \mathrm{Ni}_{10} \mathrm{Cu}_{10}$ & 468.5 & 548.6 & 80.0 & 828.0 & 683 & 0.566 & 0.854 & 0.423 & 0.289 & This work \\
\hline $\mathrm{Ce}_{55} \mathrm{Al}_{25} \mathrm{Cu}_{20}$ & 439.0 & 479.0 & 40.0 & 825.0 & 744 & 0.590 & 0.916 & 0.379 & 0.189 & {$[8]$} \\
\hline $\mathrm{Ce}_{55} \mathrm{Al}_{25} \mathrm{Cu}_{5} \mathrm{Ni}_{15}$ & 473.6 & 541.2 & 67.6 & 899.6 & - & 0.526 & 0.875 & 0.379 & 0.189 & {$[2,32]$} \\
\hline $\mathrm{Ce}_{55} \mathrm{Al}_{25} \mathrm{Cu}_{15} \mathrm{Ni}_{5}$ & 459.1 & 520.0 & 60.9 & 878.1 & - & 0.523 & 0.883 & 0.389 & 0.170 & {$[2,32]$} \\
\hline
\end{tabular}

For example, $T_{r g}$ or reduced glass transition temperature indicates that the viscosity must be higher at temperatures between the liquidus and glass transition, while $\Delta T_{X}$ is a parameter frequently cited to characterize the stability and deformability of metallic glasses ${ }^{10}$. The high value of $\gamma$ suggests that the alloy is in the state of liquid stability, while the onset crystallization temperature, $T_{x}$, could be used to roughly compare crystallization resistance during the glass formation of metallic liquids. This means that when the $T_{g} / T_{x}$ ratio decreases, crystallization resistance increases, thereby increasing the GFA. However, it is advisable to use the same heating rate due to the strong dependence of these characteristic parameters on this rate.

The results indicated that the initial melting point, $\mathrm{T}_{\mathrm{m}}$, the final melting point (liquidus temperature), $T_{l}$, and the glass transition temperature determined at a heating rate of $40 \mathrm{~K} / \mathrm{s}$ were 683,828 and $468.5 \mathrm{~K}$ respectively. These values change little in similar compositions when La or Ce instead of $\mathrm{Mm}$ are considered in the $\mathrm{Mm}_{55} \mathrm{Al}_{25} \mathrm{Ni}_{10} \mathrm{Cu}_{10}$ alloy, except for $\mathrm{La}_{55} \mathrm{Al}_{25} \mathrm{Ni}_{20}, \mathrm{La}_{55} \mathrm{Al}_{25} \mathrm{Cu}_{20}$ and $\mathrm{Ce}_{55} \mathrm{Al}_{25} \mathrm{Cu}_{10}$. It should be pointed out that $T_{m}$ generally changes very little while $T_{l}$ and $T_{g}$ change more visibly, with small compositional changes in alloys of the same system ${ }^{30,31}$. Note that high values of $\Delta T_{X}(80$ and $84 \mathrm{~K})$ were measured in the $\mathrm{Mm}_{55} \mathrm{Al}_{25} \mathrm{Ni}_{10} \mathrm{Cu}_{10}$ and $\mathrm{La}_{55} \mathrm{Al}_{25} \mathrm{Ni}_{10} \mathrm{Cu}_{10}$ alloys, respectively. However, with additions of more than 10 at. $\% \mathrm{Cu}$ (substituting $\mathrm{Cu}$ for $\mathrm{Ni}$ ), a progressive reduction was observed in the value of $\Delta T_{X}$, amounting to 38.9 and $40 \mathrm{~K}$ in the $\mathrm{La}_{55} \mathrm{Al}_{25} \mathrm{Cu}_{20}$ and $\mathrm{Ce}_{55} \mathrm{Al}_{25} \mathrm{Cu}_{20}$ alloys. This suggests that the best atomic interactions that favor GFA are obtained in RE-Al-TM alloys with additions of less than 10 at. $\% \mathrm{Cu}$. On the other hand,
$T_{r g}$ seems not to be an appropriate parameter to evaluate liquid stability in RE-Al-(Cu,Ni) amorphous alloys. On the other hand, the $\gamma, K$ and $T_{g} / T_{X}$ parameters seem suitable to evaluate the GFA of RE-Al-(Ni,Cu) alloys. High values of $\gamma$ and $K$ and low values of $T_{g} / T_{X}$ were observed in the $\mathrm{Mm}_{55} \mathrm{Al}_{25} \mathrm{Ni}_{10} \mathrm{Cu}_{10}$ and $\mathrm{LaAl}_{25} \mathrm{Ni}_{10}^{g} \mathrm{Cu}_{10}$ alloys, suggesting that these alloys present the best GFA.

\section{Conclusions}

This study focused on the crystallization, thermal stability and glass forming ability of $\mathrm{Mm}_{55} \mathrm{~A}_{25} \mathrm{Ni}_{10} \mathrm{Cu}_{10}$ amorphous alloy. Crystallization was found to occur through a multi-stage process: amorphous $\rightarrow$ metastable $+\mathrm{Mm}_{3} \mathrm{Al}$ $\rightarrow \mathrm{Mm}_{3} \mathrm{Al}+\mathrm{MmAl}(\mathrm{NiCu})+$ unknown phase. The asymmetric form of the isothermal annealing curves of the as-quenched samples indicated controlled interfacial growth during amorphous to crystalline transformation. The $\mathrm{Mm}_{55} \mathrm{~A}_{25} \mathrm{Ni}_{10} \mathrm{Cu}_{10}$ alloy presented higher GFA when than amorphous RE-Al-(Cu,Ni) alloys. It was also found that the thermal parameter $T_{r g}\left(=T_{g} / T_{l}\right)$ is not suitable for evaluating the GFA of these alloys. The $\gamma, K$ and $T g / T_{X}$ parameters suggest that the complete substitution of RE (Ce,La,Nd,Pr) metal with Mm does not affect the stability, GFA, or formation of the amorphous phase during rapid solidification.

\section{Acknowledgements}

The authors acknowledge the Brazilian research funding agency CNPq for its financial support of this work. 


\section{References}

1. Inoue $\mathrm{A}$, Zhang $\mathrm{T}$ and Masumoto $\mathrm{T}$. Al-La-Ni Amorphous Alloys with a Wide Supercooled Liquid Region. Materials Transactions. 1989; 30(12):965-972.

2. Lu ZP, Tan H, Li Y and Ng SC. The correlation between reduced glass transition temperature and glass forming ability of bulk metallic glasses. Scripta Materialia. 2000; 42:667-673. http:// dx.doi.org/10.1016/S1359-6462(99)00417-0

3. Lu ZP and Liu CT. A new glass-forming ability criterion for bulk metallic glasses. Acta Materialia. 2002; 50:3501-3512. http://dx.doi.org/10.1016/S1359-6454(02)00166-0

4. Inoue A, Nakamura T, Sugita $\mathrm{T}$, Zhang $\mathrm{T}$ and Masumoto $\mathrm{T}$. Bulky La-Al-TM (TM=Transition Metal) amorphous alloys with high tensile strength produced by a high-pressure die casting method. Materials Transactions. 1993; 34:351-358.

5. Inoue A, Zhang T, Takeuchi A and Zhang W. Hard magnetic bulk amorphous nd-fe-al alloys of $12 \mathrm{~mm}$ in diameter made by suction casting. Materials Transactions. 1996; 37:636-640.

6. Zhang B, Pan MX, Zhao DQ. "Soft" bulk metallic glasses based on cerium. Applied Physics Letters. 2004; 85:61-66. http://dx.doi.org/10.1063/1.1768308

7. Kim JH, Park JS, Jeong HT, Kim WT and Kim DH. Fabrication of Misch metal-Al-Ni-Cu-C bulk metallic glass matrix composite by gravitational casting in air atmosphere. Materials Science and Engineering A. 2004; 386:186-193. http://dx.doi. org/10.1016/j.msea.2004.07.012

8. Zhang B, Zhao DQ, Pan MX, Wang RJ and Wang WH. Formation of cerium-based bulk metallic glasses. Acta Materialia. 2006; 54:3025-3032. http://dx.doi.org/10.1016/j. actamat.2006.02.044

9. Johnson WL. Bulk Glass-Forming Metallic Alloys. Materials Research Society Bulletin. 1999; 24:42-56.

10. Inoue A. Stabilization of metallic supercooled liquid and bulk amorphous alloys. Acta Materialia. 2000; 48:279-306. http:// dx.doi.org/10.1016/S1359-6454(99)00300-6

11. Wang WH, Dong C and Shek CH. Bulk metallic glasses. Materials Science and Engineering: Reports. 2004; 44:45-89. http://dx.doi.org/10.1016/j.mser.2004.03.001

12. Zhang T, Inoue A and Masumoto T. Amorphous Zr-Al-TM $(\mathrm{TM}=\mathrm{Co}, \mathrm{Ni}, \mathrm{Cu}$ ) alloys with significant supercooled liquid region of over 100 K. Materials Transactions. 1991; 32:1005-1010.

13. Kim YC, Na JH, Park JM, Kim DH, Lee JK and Kim WT. Role of nanometer-scale quasicrystals in improving the mechanical behavior of Ti-based bulk metallic glasses. Applied Physics Letters. 2003; 83:3093-3095. http://dx.doi. org/10.1063/1.1616198

14. Lee JK, Kim SH, Kim WT and Kim DH. Precipitation of the icosahedral phase in amorphous $\mathrm{Zr}_{65} \mathrm{Cu}_{17.5-\mathrm{x}} \mathrm{Al}_{7.5} \mathrm{Ni}_{10} \mathrm{Ag}_{\mathrm{x}}$ $(\mathrm{x}=0,2.5,5,7.5$ and 10) alloys. Metals and Materials International. 2001; 7:187-190. http://dx.doi.org/10.1007/ BF03026974

15. Lee ML, Zhang Y, Li Y and Carter CW. Collected Abstracts of the 3rd International Conference on Bulk Metallic Glasses. Beijing; 2003. p.115.

16. TanH,ZhangY andLiY. Synthesis of La-based in-situ bulk metallic glass matrix composite. Intermetallics. 2002; 10:1203-1205. http://dx.doi.org/10.1016/S0966-9795(02)00148-6

17. Kim JH, Lee JY, Park JM, Fleury E, Kim WT and Kim DH. Glass Forming Ability and Mechanical Properties of Misch Metal-Based Bulk Metallic Glass Matrix Composite. Materials Transactions. 2004; 45:1395-1399. http://dx.doi.org/10.2320/ matertrans.45.1395
18. Kissinger HE. Reaction Kinetics in Differential Thermal Analysis. Analytical Chemistry. 1957; 29:1702-1706. http:// dx.doi.org/10.1021/ac60131a045

19. Guo FQ, Poon SJ and Shiglet GJ. Glass Formability in Al-based Multinary Alloys. Materials Science Forum. 2000; 331-337:31-42.

20. Blázquez JS, Fazakas E, Dimitrov H, Latuch J, Varga L and Kulik T. Effect of substitution of rare earth by mischmetal on the devitrification process of $\mathrm{Al}-\mathrm{X}-\mathrm{Ni}-\mathrm{Co}(\mathrm{X}=\mathrm{Y}, \mathrm{Ce}, \mathrm{Mm})$ alloys. Journal of Non-Crystalline Solids. 2005; 351:158-166.

21. Pradell T, Crespo D, Clavaguera N and Clavaguera-Mora MT. Diffusion controlled grain growth in primary crystallization: Avrami exponents revisited. Journal of Physics: Condensed Matter. 1998; 10:3833. http://dx.doi. org/10.1088/0953-8984/10/17/014

22. Ye F and Lu K. Crystallization kinetics of Al-La-Ni amorphous alloy. Journal of Non-Crystalline Solids. 2000; 262:228-235. http://dx.doi.org/10.1016/S0022-3093(99)00660-2

23. Hoyer W, Jodicke R. Short-range and medium-range order in liquid Au-Ge alloys. Journal of Non-Crystalline Solids. 1995; 192-193:102-105. http://dx.doi.org/10.1016/00223093(95)00335-5

24. Fromont M. Hétérodiffusion du cérium dans le lanthane cubique centré: Effet de la transformation $\beta \rightarrow$ y sur les coefficients de diffusion. Journal de Physique Lettres. 1976; 37:117-118. http://dx.doi.org/10.1051/jphyslet:01976003705011700

25. Hong SJ, Kim TS, Kim HS, Kim WT and Chun BS. Microstructural behavior of rapidly solidified and extruded Al-14wt\%Ni-14wt\%Mm (Mm, misch metal) alloy powders. Materials Science and Engineering: A. 1999; 271:469-476. http://dx.doi.org/10.1016/S0921-5093(99)00317-2

26. Jeong HT, Kim JH, Kim WT and Kim DH. The mechanical relaxations of a $\mathrm{Mm}_{55} \mathrm{Al}_{25} \mathrm{Ni}_{10} \mathrm{Cu}_{10}$ amorphous alloy studied by dynamic mechanical analysis. Materials Science and Engineering A. 2004; 385:182-186.

27. Kawamura Y, Nakamura T, Inoue A, Inoue A and Liu CT, editos. Materials Research Society Symposium Proceedings. Warrendale: Materials Research Society; 1998. vol. 554. p.373.

28. Long ZL, Shao Y, Deng XH, Zhang ZC, Jiang Y, Zhang P et al. $\mathrm{Cr}$ effects on magnetic and corrosion properties of $\mathrm{Fe}-\mathrm{Co}-\mathrm{Si}-\mathrm{B}-\mathrm{Nb}-\mathrm{Cr}$ bulk glassy alloys with high glass-forming ability. Intermetallics. 2007; 15:1453-1458. http://dx.doi. org/10.1016/j.intermet.2007.05.002

29. Long Z, Xie G, Wei H, Su X, Peng J, Zhang P et al. On the new criterion to assess the glass-forming ability of metallic alloys. Materials Science and Engineering A. 2009; 509:23-30. http:// dx.doi.org/10.1016/j.msea.2009.01.063

30. Lu ZP, Hu X, Li Y and Ng SC. Glass forming ability of $\mathrm{La}-\mathrm{Al}-\mathrm{Ni}-\mathrm{Cu}$ and $\mathrm{Pd}-\mathrm{Si}-\mathrm{Cu}$ bulk metallic glasses. Materials Science and Engineering A. 2001; 304-306:679-682. http:// dx.doi.org/10.1016/S0921-5093(00)01563-X

31. Triveño Rios C, Suriñach S, Baró MD, Bolfarini C, Botta WJ and Kiminami CS. Glass forming ability of the Al-Ce-Ni system. Journal of Non-Crystalline Solids. 2008; 354:4874-4877.

32. Lu ZP, Bei H and Liu CT. Recent progress in quantifying glass-forming ability of bulk metallic glasses. Intermetallics. 2007; 15:618-624. http://dx.doi.org/10.1016/j. intermet.2006.10.017

33. Lu ZP, Goh TT, Li Y and Ng SC. Glass formation in La-based $\mathrm{La}-\mathrm{Al}-\mathrm{Ni}-\mathrm{Cu}-(\mathrm{Co})$ alloys by Bridgman solidification and their glass forming ability. Acta Materialia. 1999; 47:2215-2224. http://dx.doi.org/10.1016/S1359-6454(99)00058-0 